\title{
Chemical Composition and Nutritional Evaluation of Pasteurized Egg Melange
}

\author{
DANIEL SIMEANU, ANDREEA CATALINA NISTOR, BOGDAN-VLAD AVARVAREI*, PAUL-CORNELIU BOISTEANU* \\ University of Agricultural Sciences and Veterinary Medicine from Iasi, 3 Mihail Sadoveanu Alley, 700490 lasi, Romania
}

\begin{abstract}
Egg is a basic foodstuff in many cultures and has a special place, also represent a rich source of nutrients such as, high quality proteins and a large variety of minerals and vitamins. The main derived products which are processed nowadays are dehydrated products (egg powder) and the liquid ones (refrigerated or frozen) as well as pasteurized egg mélange which was the studied food in the current research. A number of 20 samples of egg mélange were gathered from two different processing units. Samples were subjected to chemical analysis being determined content in water, drymatter, proteins, lipids, minerals, non-nitrogenous extractive substances, fatty acids and amino acids. Based on the obtained values was realised a nutritional evaluation for the analysed product by calculating the chemical indexes of essential amino acids $(\mathrm{Cl})$, essential amino acids index (EAAI), biological value (BV) and nutritional index (NI) for three categories of persons (children, young people and adults). The results of the current study showed the fact thatchemically speaking, the analysed pasteurized egg mélange presented values which were into the limits from literature; the analysed samples contented $75.59 \%$ water, $24.41 \%$ dry matter, $12.22 \%$ protein, $9.71 \%$ lipids, $0.99 \%$ total minerals, $1.48 \%$ non-nitrogenous extractive substances, $12.34 \mathrm{~g} / 100 \mathrm{~g}$ content in amino acids $(5.5 \mathrm{~g} / 100 \mathrm{~g}$ essential amino acids) and $22.86 \mathrm{~g} / 100 \mathrm{~g}$ lipids for polyunsaturated fatty acids. After nutritional evaluation of proteins from the studied food we observed that those ones had a very close value ( $E A A=50.77 \mathrm{~g} / 16 \mathrm{~g} \mathrm{~N}$ ) to the one of hen egg albumen $(51.2 \mathrm{~g} / 16 \mathrm{~g} \mathrm{~N})$, value which is considered etalon. Calculus of some foresight indicators for nutritional value of proteins from studied egg mélange showed the fact that this one could represent a good source of proteins and implicitly of essential amino acids for humans even if in children's case the values were a little bit lower and two amino acids (tryptophan and leucine) were slightly limiting.
\end{abstract}

Keywords: egg mélange, amino acids, biological value, fatty acids, essential amino acids index, nutritional index

Healthy diet plays an important role in improving of human life quality. Among different food products with delivery of essential nutritive substances for organism, egg is a basic foodstuff in many cultures and has a special place [1, 2].

Eggs are a rich source of nutrients such as, high quality proteins (which contain the ideal rate of amino acids for a normal functioning of human organism), a great variety of minerals and vitamins [3-5].

Eggs provide to human diet all those nine essential amino acids (EAA), making them an excellent source of proteins with a high biological value (BV). Also, eggs are frequently used as standard in comparing of proteins' quality from other foodstuffs $[6,7]$.

Being a very valuable foodstuff for humans and an indispensable raw material for food industry, at a rational consumption egg represents a real stimulant for organisms' metabolic functions, determining its resistance increasing at diseases and helping at fortifying of nervous system [8, 9].

In order to increase eggs' shelf lifetime and for a superior capitalization of them (in correlations with the preferences of the consume market and with an increasing demand of industries which use eggs as raw/auxiliary materials), were introduced in industrial processing of the so called eggs derivates or ovoproducts, foodstuffs which greatly keep the quality of natural product, buthave a much better preservation than those [10].

In according with EU regulations, ovoproduct is any product obtained from whole egg, from its constituents or from a mix of its constituents, after removal of shell and egg membranes. Egg products could be partially completed with other foodstuffs or additives [11-13].
The main derivates from eggs which are processed nowadays are dehydrated products (egg powder) and the liquid ones (refrigerated and frozen) [14].

Despite the evolution of eggs' preservation or processing techniques, these ones must respect the most strictly food safety conditions, at the same time with keeping of eggs' native nutritive qualities $[15,16]$.

Ovoproducts are often utilised in food industry and represent an opportunity for egg producers to capitalize them in other ways then in shell eggs [17, 18].

Egg products are frequently utilised as raw material in different branches of foodstuff industry and public food service, because provides a rich source of high-quality proteins, vitamins and oligo-elements [10, 19,20]. Those ones are preferred because are easy to manipulate and to store, but because are microbiological sensitive, must be subjected to pasteurization for obtaining of safety products [11-13]. Pasteurization of mélange is usually realised to decrease at minimum bacterial flora and to prolong the shelf lifetime, but must be accompanied by an aseptic wrapping. Being an ingredient of products consumed by all people categories, mélange must be microbiologically analysed in order to avoid food poisoning [21-23].

Even if nourishment habits of mankind evolved much during time, the demands of human organism remains practically the same, them satisfy being assured by consumption of various healthy and agreeable foodstuffs, which must be chosen so to assure its quantitative and qualitative demands [11-13, 24].

Eggs could add many positive attributes to foodstuff products, due to their functional properties such as: emulsifying capacity, foaming capacity, coagulating power and aroma, to name only some of them. Due to those facts,

* email: bogdan_avarvarei@yahoo.com; paulb@uaiasi.ro 
eggs are utilised in many foodstuff products. Nowadays, it is a tendency for utilization of many products processed with eggs. Those products could be classified as refrigerated liquids, frozen and dried products. Traditionally, eggs are commercialized as eggs in shell, but in the last years increased the consumption of eggs under the form of egg products [24-26].

\section{Experimental part}

Materials and methods

Analysis were carried out on pasteurized yolk and albumen samples, utilized as raw material in many branches of food industry and not only.

The analysed material consisted in 20 samples which were gathered from two different production units.

Chemical composition of mélange was determined as follows: determination of dry matter was made in according with AOAC no. 925.30 [27-29] method, and water content resulted by difference in according with the formula: Water $(\%)=100 \%-\mathrm{DM}(\%)$.

Content in proteins resulted by multiplication of total nitrogen content with 6.25 , and determination of total nitrogen was realised through Kjeldahl method in according with AOAC no. $925.31[14,27,30]$.

Content in lipids was determined through Soxhlet method in according with AOAC no. 925.32 [27], content in total mineral substances was determined by carbonization of samples follow ed by their calcinations in according with AOAC no. 900.02 method [27].

Non-nitrogenous extractive substances were calculated by difference using the following formula:

NES\% $=100$-(Water $\%$ + Ash $\%$ + Protein $\%$ + Lipids $\%)$.

Amino acids determination was realised through liquid chromatography which supposed the amino acids detachment from protein molecule by acid hydrolysis. Amino acids are determined after samples' derivation with ortophtalaldehide and detection at $338 \mu \mathrm{m}$. Method was effectuated in according with standard SR EN ISO 13903:2005 [31, 32], concentration calculus being made by reporting of drops area to calibration curve.

Determination of fatty acids from analysed samples was made by chromatographic method and supposed the transformation of fatty acids into methyl esters and after that separation in chromatographic column and comparison of results with standard chromatogram, as well as the percentage quantification of those. Preparation of methyl esters was realised in according with standard ISO 5508:2002 [33-36]. Results being expressed in percent of fatty acids methyl esters.

The analysis' results were statistically processed being calculated the position and variation estimators (arithmetic mean; mean's standard deviation $\mathrm{S}$ and variation coefficient V\%) [37-39].

To determine the nutritive value of pasteurized egg mélange was utilised the theoretical relation based on quantity of gross energy liberated at burning of one gram of proteins, fats and carbohydrates in bomb calorimeter, in according with formula [40-44]:

$\mathrm{GE}(\mathrm{kcal} / 100 \mathrm{~g})=5.70 \mathrm{kcal} \times \mathrm{g}$ proteins $+9.50 \mathrm{kcal} \times \mathrm{g}$ fats $+4.2 \mathrm{kcal} \times \mathrm{g}$ NES.

Proteins' quality was estimated through chemical methods which appreciate their value based on content in essential amino acids. After determination of essential amino acids, appreciation was realised by calculus of chemical indicators $(\mathrm{Cl})$, reporting the amino acids of studied protein to amino acids of etalon protein [42-45]:

$$
\mathrm{CI}=\frac{\text { content in amino acid } \mathrm{A} \text { of studied protein }}{\text { content in amino acid } \mathrm{A} \text { of etalon protein }} \times 100 \text {. }
$$

As standard protein usually is utilised protein from egg or etalon protein FAO/WHO/UNU. In the current paper nutritional value of proteins was calculated function of standard demands for amino acids of young people (standard 1) (Tryptophan -1, Threonine -4, Isoleucine -4, Leucine -7, Lysine -5.5, Methionine + Cysteine -3.5, Phenylalanine + Tyrosine - 6 , Valine -5 ; EAA $=36 \mathrm{~g} / 16 \mathrm{~g} \mathrm{~N}$ ) [44, 46], adult persons (standard 2) (Tryptophan -0.6, Threonine -2.6, Isoleucine -3, Leucine -4.4, Lysine -3.1, Methionine + Cysteine -2.7, Phenylalanine + Tyrosine 3.3, Valine -2.3; EAA = $22 \mathrm{~g} / 16 \mathrm{~g} \mathrm{~N}$ ) [47-49] and for children (standard 3) (Tryptophan -1.7, Threonine -4.3, Isoleucine 4.6, Leucine -9.3, Lysine -6.6, Methionine + Cysteine -4.2, Phenylalanine + Tyrosine -7.2, Valine -5.5; EAA = $37.9 \mathrm{~g} /$ $16 \mathrm{~g} \mathrm{~N}$ ) [50].

After calculating of chemical indexes for those 8 essential amino acids, was calculated Oser index or EAAl (Essential Amino Acid Index) [43, 46, 49, 51]:

\section{EAAI $=\sqrt[n]{\mathrm{CI} 1 \times \mathrm{CI} 2 \times \mathrm{CI} 3 \times \ldots \times \mathrm{CIn}}$}

Biological value (BV) was calculated in according with the method described by Oser [44,52], using the following formula:

$$
\mathrm{BV}=1.09 \text { (EAAl) }-11.7 .
$$

Nutritional index (NI) of pasteurized egg melange was calculated using the formula described by Crisan and Sands, 1978 [44, 53]:

\section{Results and discussions}

$$
\mathrm{NI}(\%)=\frac{\text { EAAI } \times \% \text { protein }}{100} .
$$

Chemical indicators were appreciated in connection with the quality of analysed products.

Regarding water content, was identified a mean value of $75.59 \pm 0.04 \%$, with a recorded maximum of $75.80 \%$ and a minimum of $75.40 \%$.

This component of melange proved to be a very homogenous character, aspect confirmed by the very low value for variability coefficient, of only $0.2 \%$ (table 1 ).

Literature allows to pasteurized egg mélange values for water content between $74.4 \%$ and $77.86 \%[54,55]$.

Dry matter content in melange studied by us was, in average, $24.41 \pm 0.04 \%$, minimum value being $24.20 \%$, and the maximum one being $24.60 \%$.

Variability coefficient value was of only $0.63 \%$ which shown the uniformity of studied feature.

Minimum limit for dry matter content in according with technical specifications is $22.5 \%$. Literature cite for dry matter in mélange levels of 22.14-25.6\% [54, 55].

Determination for protein content in the studied melange show the fact that really egg is a protein matrix, the obtained result for fresh product being $12.22 \pm 0.04 \%$; technical specifications which come with the product indicate a protein content of minimum $11.15 \%$.

Lamas et al., in 2016 [55] realising a study regarding nutritional composition of some types of fresh liquid ovoproducts obtained a protein content of $10.56 \%$, while Darvish et al., in 2012 [56] identify a value of $12.56 \%$ for fresh melange.

At the end of determinations regarding lipids content in pasteurized egg mélange was founded a mean percent of $9.71 \pm 0.03 \%$, with a minimum of $9.50 \%$ and a maximum of $9.80 \%$. Lipids content indicated by manufacturer of analysed ovoproduct is of minimum $8 \%$.

The very good homogeneity of analysed component is given by the value of $1.22 \%$ for variability coefficient.

Studies realised by Lamas et al., 2016 [55], Darvish et al., 2012 [56] and Dogruer et al., 2015 [57] regarding 


\begin{tabular}{|l|c|c|c|c|}
\hline \multirow{2}{*}{ Specification } & \multicolumn{4}{|c|}{ Statistic estimators } \\
\cline { 2 - 5 } & $\pi_{-\pi_{0}}(\%)$ & V\% & Min. & Max. \\
\hline Water & $75.59 \pm 0.04$ & 0.20 & 75.40 & 75.80 \\
\hline Dry matter & $24.41 \pm 0.04$ & 0.63 & 24.20 & 24.60 \\
\hline Proteins & $12.22 \pm 0.04$ & 1.26 & 12.10 & 12.40 \\
\hline Lipids & $9.71 \pm 0.03$ & 1.22 & 9.50 & 9.80 \\
\hline Total mineral substances & $0.99 \pm 0.01$ & 0.51 & 0.99 & 1.00 \\
\hline Non-nitrogenous extractive substances & $1.49 \pm 0.04$ & 10.09 & 1.31 & 1.66 \\
\hline
\end{tabular}

chemical composition of several ovoproduct types highlight the fact that pasteurized mélange contain $8.11 \%$ $10.38 \%$ lipids.

For pasteurized egg melange, the obtained mean value regarding total mineral substances content was $0.99 \pm 0.01 \%$, with a variability coefficient of $0.51 \%$ fact which shown a very good homogeneity for the analysed indicator.

Research realised by Souci et al., 1994 [ 58] and Lamas et al., 2016 [55] highlight the fact that in fresh melange rate of ash content is $0.99-1.35 \%$.

Non-nitrogenous extractive substances content recorded a mean value of $1.48 \pm 0.04 \%$. Homogeneity of feature was a medium one, variability coefficient value being $10.09 \%$.

Energetic value of pasteurized egg melange was 168.16 $\mathrm{kcal} / 100 \mathrm{~g}$ product or $702.91 \mathrm{MJ} / 100 \mathrm{~g}$ products. Those values are very close to energetic value of whole egg, but around 2.2 times lower than yolk and around 3.3 times lower than integral egg powder. Also, we observed that energetic value of pasteurized egg mélange is with around 2.9 times higher than albumen [59-61].

Nutritive value of proteins from egg was strongly researched, being the result of ideal balance of indispensable amino acids [60,62] .

Results of amino acids analysis from pasteurized egg mélange are presented in correlation with variation limits founded in literature both for pasteurized egg mélange, as well as for raw mélange. So, was observed that sum of amino acids is $12.34 \mathrm{~g} / 100 \mathrm{~g}$ in analysed product and authors like Kassis et al., 2010 [50] and Darvish et al., 2012 [56] presented variation limits for amino acids from pasteurized egg mélange between 12.37 and $13.60 \mathrm{~g} / 100$ g.

Analysis of essential amino acids indicates a total value of $5.5 \mathrm{~g} / 100 \mathrm{~g}$. The main constituent was leucine with a mean value of $1.09 \pm 0.01 \mathrm{~g} / 100 \mathrm{~g}$ and the lowest value being recorded for tryptophan which was $0.19 \pm 0.01$ $\mathrm{g} / 100 \mathrm{~g}$ (table 2).

Variation limits founded in literature $[50,63]$ for total essential amino acids were between 5.09 and $6.04 \mathrm{~g} / 100$ $\mathrm{g}$ for pasteurized melange.

Total of determined non-essential amino acids was 6.13 $\mathrm{g} / 100 \mathrm{~g}$, preponderant in their case being glutamic acid
Table 1

CHEMICAL QUALITY INDICATORS OF PASTEURIZED EGG MELANGE

Table 2

AMINO ACIDS CONTENT OF PASTEURIZED EGG MELANGE

\begin{tabular}{|l|c|c|}
\hline \multirow{2}{*}{ Amino acids } & \multicolumn{2}{|c|}{ Statistic estimators } \\
\cline { 2 - 3 } & $\pi+\bar{x}_{\bar{x}}(\mathrm{~g} / 100 \mathrm{~g})$ & $\mathrm{V} \%$ \\
\hline Tryptophan & $0.19 \pm 0.01$ & 1.14 \\
\hline Threonine & $0.66 \pm 0.02$ & 1.01 \\
\hline Isoleucine & $0.69 \pm 0.02$ & 0.10 \\
\hline Leucine & $1.09 \pm 0.01$ & 0.12 \\
\hline Lysine & $1.03 \pm 0.01$ & 0.21 \\
\hline Methionine & $0.38 \pm 0.01$ & 1.24 \\
\hline Phenylalanine & $0.65 \pm 0.02$ & 0.20 \\
\hline Valine & $0.81 \pm 0.01$ & 0.14 \\
\hline Histidine & $0.34 \pm 0.02$ & 1.27 \\
\hline Alanine & $0.76 \pm 0.01$ & 0.14 \\
\hline Arginine & $0.97 \pm 0.01$ & 0.20 \\
\hline Aspartic acid & $1.07 \pm 0.01$ & 0.33 \\
\hline Glycine & $0.31 \pm 0.01$ & 0.19 \\
\hline Glutamic acid & $1.34 \pm 0.01$ & 0.32 \\
\hline Serine & $0.83 \pm 0.01$ & 0.16 \\
\hline Proline & $0.51 \pm 0.01$ & 1.15 \\
\hline Tyrosine & $0.50 \pm 0.01$ & 0.32 \\
\hline Cysteine & $0.21 \pm 0.01$ & 1.33 \\
\hline Eamino acids & \multicolumn{2}{|c|}{12.34} \\
\hline E essential amino acids & 5.50 \\
\hline E semi-essential amino acids & \multicolumn{2}{|c|}{0.71} \\
\hline Enon-essential amino acids & 6.13 \\
\hline
\end{tabular}

with a mean content of $1.34 \pm 0.01 \mathrm{~g} / 100 \mathrm{~g}$, and the lowest rated belonging to glycine at which the mean value was $0.31 \pm 0.01 \mathrm{~g} / 100 \mathrm{~g}$.

Concluding, the obtained data regarding amino acids content from pasteurized egg melange indicate a total value of $12.34 \mathrm{~g} / 100 \mathrm{~g}$, from which $5.5 \mathrm{~g} / 100 \mathrm{~g}$ were essential amino acids, $0.71 \mathrm{~g} / 100 \mathrm{~g}$ were semi-essential amino acids and $6.13 \mathrm{~g} / 100 \mathrm{~g}$ non-essential amino acids; those values reinforced the idea that eggs or fresh and pasteurized ovoproducts represent basic foods with major beneficial on organism's grow $n$ and development but also on maintaining of a good health state of it.

After obtaining the results regarding amino acids content was calculate the content in essential amino acids related to $100 \mathrm{~g}$ protein (in $\mathrm{g} / 16 \mathrm{~g} \mathrm{~N}$, equivalent to $\mathrm{g} / 100 \mathrm{~g}$ protein) and after that was obtained the nutritional value of pasteurized egg mélange by calculating chemical indexes, EAAI, BV and nutritional index (table 3).
Table 3

CONTENT IN AMINO ACIDS AND PROTEIN'S NUTRITIVE VALUE FROM STUDIED MELANGE

\begin{tabular}{|l|c|c|c|c|}
\hline \multirow{2}{*}{ Amino acids } & \multirow{2}{*}{$(\mathrm{g} / 16 \mathrm{~g} \mathrm{~N})$} & \multicolumn{3}{|c|}{ Chemical indexes } \\
\cline { 3 - 5 } & & Standard I & Standard 2 & Standard 3 \\
\hline Tryptophan & 1.55 & 155.00 & 258.33 & 91.18 \\
\hline Threonine & 5.40 & 135.00 & 207.69 & 125.58 \\
\hline Isoleucine & 5.64 & 141.00 & 188.00 & 122.61 \\
\hline Leucine & 8.91 & 127.28 & 202.50 & 95.80 \\
\hline Lysine & 8.42 & $\mathbf{1 5 3 . 0 9}$ & $\mathbf{2 7 1 . 6 1}$ & $\mathbf{1 2 7 . 5 7}$ \\
\hline Methionine + Cystine & 4.82 & $\mathbf{1 3 7 . 7 1}$ & $\mathbf{1 7 8 . 5 2}$ & $\mathbf{1 1 4 . 7 6}$ \\
\hline Phenylalanine + Tyrosine & 9.41 & 156.83 & 285.15 & 130.69 \\
\hline Valine & 6.62 & 132.40 & 287.82 & 120.36 \\
\hline EAA & 50.77 & - & - & - \\
\hline EAAI (\%) & - & 141.90 & $\mathbf{2 3 1 . 0 7}$ & 115.18 \\
\hline P-BV & - & $\mathbf{1 4 2 . 9 7}$ & $\mathbf{2 4 0 . 1 7}$ & $\mathbf{1 1 3 . 8 5}$ \\
\hline Nutritional index (\%) & - & $\mathbf{1 7 . 3 4}$ & $\mathbf{2 8 . 2 3}$ & $\mathbf{1 4 . 0 7}$ \\
\hline
\end{tabular}


Differences between chemical indexes values $(\mathrm{Cl})$ for pasteurized egg melange depend of utilised nutritional standards: standard 1 -content in essential amino acids of ideal protein for young people, standard 2 -for mature adults and standard 3 -for children. Having in view the abovementioned situations, only in children's case were observed limiting amino acids (tryptophan and leucine), reason to affirm that for young people and adults pasteurized egg mélange represent a very good source for essential amino acids.

Proteins from pasteurized egg melange are characterised by a high nutritional value. This thing was confirmed, in the currentstudy, by the content in exogenous amino acids (EAA) which was $50.77 \mathrm{~g} / 16 \mathrm{~g} \mathrm{~N}$, very close to value of hen egg albumen ( $51.2 \mathrm{~g} / 16 \mathrm{~g} \mathrm{~N}$ ) utilised in nutritional evaluations as etalon protein for essential amino acids content [44].

Predicted nutritional values for proteins from pasteurized egg mélange (EAAI, BV and NI) were calculated on the basis of those three standards $-1,2$ and 3 . Comparing the obtained results for those three categories of persons was remarked that the lowest values were obtained for children. So, EAAI (\%) and nutritional index $\mathrm{NI}(\%)$ had values reduced with 23.2-100.6\% and P-BV was lower with 25.6$110.9 \%$.

Having in view the above-mentioned things we can affirm that pasteurized egg mélange could represent a good protein source and implicit of essential amino acids for humans even if in children's case the values were a little bit lower and two amino acids were slightly limiting. Combining pasteurized egg melange with other foods such as cheeses will lead to obtain of some protein mixes with a high biological value even for children.

In parallel with dosage of lipids from the analysed product by us were determined the fatty acids.

\section{Composition of fatty acids}

Lipids are formed by $30-35 \%$ saturated fatty acids, 40 $45 \%$ monounsaturated fatty acids (MUFA) and $20-25 \%$ polyunsaturated fatty acids (PUFA) [64].

Around $20 \%$ from total lipids are represented by fatty acids, from which $90 \%$ are omega 6 PUFA and $10 \%$ omega 3 PUFA.

Rate $\omega-6 / \omega-3$ is $9: 1$, so to improve this rate are utilised some supplements rich in $\omega-3$, because was demonstrated the fact that a rate of $5: 1$ could decrease the risk for thrombosis, inflammation of vascular wall and prevent the myocardium arrhythmia at humans $[65,66]$.

Data obtained regarding saturated fatty acids show that the main constituent was palmitic acid with a mean value of $25.03 \pm 0.09 \mathrm{~g} / 100 \mathrm{~g}$ lipids, and constituent with the lowest rate was represented by heptadecanoic acid $(0.13 \pm 0.01 \mathrm{~g} / 100 \mathrm{~g}$ lipids). Total of saturated fatty acids from the studied melange was $34.57 \mathrm{~g} / 100 \mathrm{~g}$ fat (table 4).

Results regarding monounsaturated fatty acids revealed a total value of $42.33 \mathrm{~g} / 100 \mathrm{~g}$ lipids, the lowest mean value being recorded for pentadecenoic acid, $0.05 \pm 0.01 \mathrm{~g} / 100 \mathrm{~g}$ lipids, opposite being oleic acid with $38.37 \pm 0.08 \mathrm{~g} / 100 \mathrm{~g}$ lipids.

Regarding polyunsaturated fatty acids, the recorded total value was $22.86 \mathrm{~g} / 100 \mathrm{~g}$ lipids, the highest rate belonging to linoleic acid with a mean of $17.57 \pm 0.11 \mathrm{~g} / 100 \mathrm{~g}$ lipids, while docosapentaenoic acid recorded the lowest rate $0.04 \pm 0.01 \mathrm{~g} / 100 \mathrm{~g}$ lipids.

In contrast to fatty acids from raw mélange, the results obtained for analysed pasteurized egg mélange recorded values, into the limits from literature, being between 31.30 and $35.07 \%$ for total saturated fatty acids as well as for monounsaturated fatty acids $(39.07-45.8 \%)$ and polyunsaturated ones (16.3-19.59\%) [55, 67-69].

\begin{tabular}{|c|c|c|c|c|}
\hline \multirow[b]{2}{*}{ Fatty acids } & \multicolumn{4}{|c|}{ Statistical estimators } \\
\hline & $\begin{array}{c}\pi-\pi \\
(\mathrm{g} / 100 \mathrm{~g} \text { lipids })\end{array}$ & $\mathrm{V} \%$ & Min. & Max. \\
\hline Myristic C14:0 & $0.33 \pm 0.01$ & 10.00 & 0.29 & 0.38 \\
\hline Pentadecanoic C15:0 & $0.06 \pm 0.01$ & 17.81 & 0.05 & 0.08 \\
\hline Palmitic C16:0 & $25.03 \pm 0.09$ & 0.87 & 24.73 & 25.31 \\
\hline Heptadecanoic C17:0 & $0.13 \pm 0.01$ & 15.02 & 0.1 & 0.15 \\
\hline Stearic C18:0 & $9.01 \pm 0.07$ & 1.80 & 8.84 & 9.21 \\
\hline$\Sigma$ saturated fatty acids & 34.57 & - & - & - \\
\hline Myristoleic C14:1 & $0.06 \pm 0.01$ & 16.66 & 0.05 & 0.08 \\
\hline Pentadecenoic C15:1 & $0.05 \pm 0.01$ & 31.62 & 0.03 & 0.07 \\
\hline Palmitoleic C16:1 & $3.48 \pm 0.02$ & 1.82 & 3.41 & 3.57 \\
\hline Heptadecenoic C17:1 & $0.07 \pm 0.01$ & 17.27 & 0.05 & 0.08 \\
\hline Oleic C18: $\ln 9$ & $38.37 \pm 0.08$ & 0.51 & 38.17 & 38.67 \\
\hline Erucic C22:1n9 & $0.09 \pm 0.01$ & 35.31 & 0.05 & 0.13 \\
\hline Nervonic C24: $\ln 9$ & $0.22 \pm 0.01$ & 14.11 & 0.18 & 0.25 \\
\hline$\Sigma$ monounsaturated fatty acids & 42.33 & - & - & - \\
\hline Linoleic C18:2n6 & $17.57 \pm 0.11$ & 1.46 & 17.22 & 17.88 \\
\hline Linolenic $\gamma$ C18:3n6 & $0.11 \pm 0.01$ & 21.11 & 0.08 & 0.13 \\
\hline Linolenic $\alpha$ C18:3n 3 & $0.23 \pm 0.01$ & 13.74 & 0.2 & 0.28 \\
\hline Eicosadienoic C20:2n6 & $0.14 \pm 0.01$ & 10.44 & 0.12 & 0.16 \\
\hline Eicosatrienoic C20:3n6 & $0.16 \pm 0.01$ & 19.54 & 0.12 & 0.19 \\
\hline Eicosatrienoic C20:3n3 & $0.18 \pm 0.01$ & 21.06 & 0.14 & 0.23 \\
\hline Arachidonic C20:4n6 & $2.90 \pm 0.02$ & 1.87 & 2.83 & 2.98 \\
\hline Docosatetraenoic C22:4n6 & $0.96 \pm 0.01$ & 2.80 & 0.92 & 0.99 \\
\hline Docosapentaenoic C22:5n3 & $0.04 \pm 0.01$ & 22.01 & 0.03 & 0.05 \\
\hline Docosahexaenoic C22:6n3 & $0.57 \pm 0.01$ & 7.12 & 0.51 & 0.62 \\
\hline$\Sigma$ polyunsaturated fatty acids & 22.86 & - & - & - \\
\hline$\Omega 3$ & 1.02 & - & - & - \\
\hline$\Omega 6$ & 21.84 & - & - & - \\
\hline$\Omega 6 / \Omega 3$ & & 21.53 & & \\
\hline PUFA/MUFA & & 0.54 & & \\
\hline
\end{tabular}

Table 4

FATTY ACIDS CONTENT OF PASTEURIZED EGG MELANGE 


\section{Conclusions}

The results of the current study highlight the fact the chemically speaking the analysed pasteurized egg mélange presented values which were into the limits from consulted literature; analysed samples contained $75.59 \%$ water, $24.41 \%$ dry matter, $12.22 \%$ protein, $9.71 \%$ lipids, $0,99 \%$ total minerals and $1.48 \%$ non-nitrogenous extractive substances.

Speaking about amino acids content, in the studied pasteurized egg melange, was founded a total of $12.34 \mathrm{~g} /$ $100 \mathrm{~g}$, from $5.5 \mathrm{~g} / 100 \mathrm{~g}$ which were essential amino acids, $0.71 \mathrm{~g} / 100 \mathrm{~g}$ were semi-essential amino acids and $6.13 \mathrm{~g} /$ $100 \mathrm{~g}$ non-essential amino acids; these values reinforced the idea that eggs or fresh and pasteurized ovoproducts represent basic foods with major beneficial on organism's grown and development butalso on maintaining of a good health state of it.

After nutritional evaluation of proteins for pasteurized egg melange we noticed that those ones had a very close value $(E A A=50.77 \mathrm{~g} / 16 \mathrm{~g} \mathrm{~N})$ to the one of hen egg albumen $(51.2 \mathrm{~g} / 16 \mathrm{~g} \mathrm{~N})$, value which is considered etalon. Calculus of some prediction indicators for nutritional value of proteins from studied egg mélange (EAAI, BV and $\mathrm{NI}$ ) for three categories of persons (children, young people and adults) indicated the fact that studied food could represent a good protein source and implicit of essential amino acids for humans even if in children's case the values were a little bit lower and two amino acids (tryptophan and leucine) were slightly limiting. Combination of pasteurized egg mélange with other foods such as cheeses will lead to obtain of some protein mixes with a high biological value even for children.

Results obtained regarding mélange content in fatty acids highlighted a total value for the saturated ones of $34.57 \mathrm{~g} / 100 \mathrm{~g}$ lipids, $42.33 \mathrm{~g} / 100 \mathrm{~g}$ lipids for the monounsaturated ones and $22.86 \mathrm{~g} / 100 \mathrm{~g}$ lipids for polyunsaturated acids; all values being into the limits from consulted literature.

Having in view the above-mentioned things we recommend the consumption of pasteurized egg mélange because presents normal chemical characteristics, in according with the legislation and due to the fact, that have a very good nutritional value for adults and good enough for children.

\section{References}

1.NACU, G., BOLOGA, M., POP, C., BOISTEANU, P.C., SIMEANU, D., DOLIS, M.G., DONOSA, R., Rev. Chim. (Bucharest), 69, no. 3, 2018, p. 682.

2.CRISTE, F.L., MIERLITA, D., SIMEANU, D., BOISTEANU, P.C., POP I.M., GEORGESCU, G., NACU, G., Rev. Chim. (Bucharest), 69, no. 9, 2018, p. 2454.

3.SIMEANU, D., GAVRILAS, A., SIMEANU, C., Lucrari Stiintifice, Seria Medicina Veterinara, 52, nr. 10, USAMV Iasi, Ed. Ion Ionescu de la Brad, Iasi, 2009, p. 1142.

4.DARVISHI, H., KHOSHTAGHZA, M.H., ZAREIN, M., AZADBAKHT, M., Agric. Eng. Int.: CIGR Journal, 5, no. 1, 2012, p. 210.

5.SIMEANU, D., POP, I.M., SIMEANU, C., STEFLEA L.M., Lucrari Stiintifice, Seria Zootehnie, 58, nr. 17, USAMV Iasi, Ed. Ion Ionescu de la Brad, lasi, 2012 p. 172.

6.HERRON, K.L., FERNANDEZ, M.L., The J ournal of Nutrition, 134, 2004, p. 187.

7.MARIN, M., DINITA, G., NICOLAE, C., MARIN, I., The $1^{\text {st }}$ Global Virtual Conference, Zilina, Slovakia, 1, 2013, p. 665.

8.RADU-RUSU, C.G., POP, I.M., SIMEANU, D., Lucrari Stiintifice, Seria Zootehnie, 53, nr. 15, USAMV Iasi, Ed. Ion Ionescu de la Brad, Iasi, 2010, p. 153.
9.CLARK, S., JUNG, S., LAMSAL, B., Food Processing: Principles and Applications, $2^{\text {nd }}$ edition, Ed. Wiley Blackwell, 2014, p. 121.

10.ROSSI, M., CASIRAGHI, E., PRIMAVESI, L., POMPEI, C., HIDALGO, A., Food Science and Technology, 43, no. 3, 2010, p. 436.

11.NISTOR, A.C, NISTOR (COTFAS), L.I., ALBU, A., USTUROI, M.G., Lucrari Stiintifice, Seria Zootehnie, 64, nr. 20, 2015, p. 100.

12.NISTOR, A.C., ALBU, A., RADU-RUSU, R.M., USTUROI, M.G., Lucrari Stiintifice, Seria Zootehnie, 66, nr. 21, 2016, p. 120.

13. NISTOR, A.C., NISTOR (COTFAS), L.I., DUMINICA, C.G., USTUROI, M.G., Bulletin of University of Agricultural Sciences and Veterinary Medicine Cluj-Napoca, Food Science and Technology, 73, no. 2, 2016, p. 139.

14.RATU, R.N., USTUROI, M.G., SIMEANU, D., SIMEANU, C., USTUROI, A., DOLIS, M.G., Mat. Plast., 54, no. 2, 2017 p. 368.

15.SZITA, G., GYETVAI, B., SZITA, J., GYENES, M., SOLYMOS, N., SOOS, L., HAJ OS, A., TOTH, P., BERNATH, S., Acta Veterinaria Brno, 77, no. 1, 2008, p. 143.

16.USTUROI, A., SIMEANU, C., USTUROI, M.G., DOLIS, M.G., RATU, R.N., SIMEANU D., Mat. Plast., 54, no. 2, 2017 p. 380.

17.LABBE, R.G., GARCIA, S., Guide to foodborne pathogens, Ed. WileyInter-science, New York, 2001, p. 1.

18.WONG, P.Y., KITTS, D., Journal of the Science of Food and Agriculture, 83, 2003, p. 44.

19.PATRIGNANI, F., VANNINI, L., KAMDEM, S.L.S., HERNANDO, I., MARCO-MOLÉS, R., GUERZONI, M.E., LANCIOTTI, R., Food Microbiology, 36, no. 1, 2013, p. 63.

20.NADERI, N., POULIOT, Y., HOUSE, J.D, DOYEN, A., J ournal of Agricultural and Food Chemistry, 65, no. 35, 2017, p. 7774.

21.GURTLER, J.B., HINTON, A. JR., BAILEY, R.B., CRAY, W.C.JR., MEINERSMANN, R.J., BALL, T.A., JIN, T.Z., International J ournal of Food Microbiology, 206, 2015, p. 109.

22.TRIPATHY, B., International J ournal of Conservation Science, 7(4), 2016, p. 1105.

23.PEREIRA, M.U., SPISSO, B.F., JACOB, S.D., MONTEIRO, M.A., FERREIRA, R.G., CARLOS, B.D., LEY DA NOBREGA, A.W., Food Chemistry, 196, 2016, p. 130.

24.DE J ESÚS, M.N., ZANQUI, A.B., VALDERRAMA, P., TANAMATI, A., MARUYAMA, S.A., DE SOUZA, N.E., MATSUSHITA, M., Food Sci. Technol., 33, no. 3, 2013, p. 549.

25.CRINGANU, I., NICOLAE, C., URDES, L., Session of scientific papers, Faculty of Animal Science and Biotechnics, Timisoara, Vol. XXXLVIII, 2005, p. 431.

26.REGO, I.O.P., MENEZES, L.D.M., FIGUEIREDO, T.C., OLIVEIRA, D.D., ROCHA, J.S.R., LARA, L.J.C., LIMA, A.L., SOUZA, M.R., CANCADO, S.V., Poultry Science, 93, no. 4, 2014, p. 1018.

27.*** AOAC, Official methods of analysis, $13^{\text {th }}$ ed. Food composition, Additives, Natural contaminants Eggs and eggs products (chapter 24). Association of Official Analytical Chemists, Inc. Arlington, Virginia, USA, 1990, p. 1018.

28.MANOLACHE, F.A., HANGANU, A., DUTA, D.E., BELC, N., MARIN, D.I., Rev. Chim. (Bucharest), 64, no. 1, 2013, p. 45.

29.DOLIS, M.G., BOISTEANU, P.C., SIMEANU, D., Rev. Chim. (Bucharest), 68, no. 6, 2017, p. 1459.

30.IOVAN, M., RADU, F., ROTARU, L., Rev. Chim. (Bucharest), 67, no. 5, 2016, p. 902.

31.VARZARU, I., UNTEA, A., TEODOR, E.M., OLTEANU, M., PANAITE, T.D., SCHITEA, M., VAN, I., Rev. Chim. (Bucharest), 64, no. 7, 2013, p. 673.

32.PLAVAN, V., MIU, L., GORDIENKO, I., IBRAGIMOVA, A., GAVRILYUK, N., Rev. Chim. (Bucharest), 64, no. 6, 2013, p. 603.

33.SARBU, C., Rev. Chim., (Bucharest), 50, no. 12, 1999, p. 852.

34.CHIRA, N.A., BRATU, A., MIHALACHE, M., TODASCA, M., DORNEANU, A., ROSCA, S.I., Rev. Chim. (Bucharest), 65, no. 7, 2014, p. 774.

35.RAICIU, A.D., POPESCU, M., IVOPOL, G.C., BORDEI, N., ALEXANDRU, G., CRISAN, I., MANEA, S., DIMA, S.O., Rev. Chim. (Bucharest), 67, no. 12, 2016, p. 2449.

36.COPOLOVICI, D., BUNGAU, S., BOSCENCU, R., TIT, D.M., COPOLOVICI, L., Rev. Chim. (Bucharest), 68, no. 3, 2017, p. 507. 
37.SANDU, G., Modele experimentale in zootehnie, Ed. Coral Sanivet, Bucuresti, 1995, p. 74.

38.DOLIS, M.G., SIMEANU, C., USTUROI, A, SIMEANU, D., Rev. Chim. (Bucharest), 68, no. 1, 2017, p. 151.

39.LUP, F., POP, I.M., SIMEANU, D., VICAS, S., SIMEANU, C., MIERLITA, D., Rev. Chim. (Bucharest), 69, no. 1, 2018, p. 222.

40.STOICA, I., STOICA, LILIANA, Bazele nutritiei si alimentatiei animalelor, Ed. Coral Sanivet, Bucuresti, 2001, p. 148.

41.HALGA, P., POP, I.M., AVARVAREI, T., POPA, V., Nutritie si alimentatie animala, Ed. Alfa, lasi, 2005, p. 94.

42.SEGAL, R., Principiile nutritiei, Ed. Academica, Galati, 2002, p. 50. 43.SIMEANU, D., Nutritie umana, Ed. Ion Ionescu de la Brad, Iasi, 2015, p. 46.

44.MIERLITA, D., SIMEANU, D., POP, I.M., CRISTE, F.L., POP, C., SIMEANU, C., LUP, F., Rev. Chim. (Bucharest), 69, no. 2, 2018, p. 453. 45.NICOLAE, M., SONEA, C., Nutreturile, valorile lor nutritive si necesarul animalelor, Ed. Ex Terra Aurum, Bucuresti, 2017, p. 36. 46.SIMEANU, C., SIMEANU, D., POPA, A., USTUROI, A., BODESCU, D., DOLIS, M.G., Rev. Chim. (Bucharest), 68, no. 5, 2017, p. 1063.

47.*** FAO/WHO, Protein quality evaluation, Report of J oint FAO/ WHO Export Consultant, FAO food Nutrition paper, 51, 1991, p. 19. 48.*** FAO, Protein and amino acid requirements in human nutrition, Report of J oint WHO/FAO/UNU Expert Consultation, WHO Technical Reort Series, 935, 2007, p. 15.

49.KOTLARZ, A., SUJAK, A., STROBEL, W., GRZESIAK, W., Vegetable Crops Research Bulletin, 75, 2011, p. 57.

50.KASSIS N.M., BEAMER, S.K., MATAK, K.E., TOU, J.C., J ACZYNSKI, J ., LWT - Food Science and Technology, 43, 2010, p. 1204.

51.SUJAK, A., KOTLARZ, A., STROBEL, W., Food Chem., 98, 2006, p. 711.

52.OSER, B.L., An integrated essential amino acid index for predicting the biological value of proteins, In A.A. Albanese (Ed.), Protein and amino acid nutrition, New York: Academic Press, 1959, pp. 295.

53.CRISAN, E.V., SANDS, A., Biology and cultivation of edible mushrooms, Hangeri Academic Press, New York, 1978, p. 137. 54.NYS, Y., SAUVEUR, B., INRA Prod. Anim., 17, 2004, p. 385.
55.LAMAS, A., ANTON, X., MIRANDA, J.M., ROCA-SAAVEDRA, P., CARDELLE-COBAS, A., RODRIGUEZ, J.A., FRANCO, C.M., CEPEDA, A., CyTA - Journal of Food, 14, no. 2, 2016, p. 289.

56.DARVISHI, H., HADI KHOSHTAGHAZA, M., ZAREIN, M., AZADBAKHT, M., Agric. Eng. Int.: CIGR J ournal, 14, no. 4, 2012, p. 224.DOĐRUER, Y., TELLÝ, N., TELLY, A.E., KAHRAMAN, H.A., GÜNER, A., Eurasian J ournal of Veterinary Sciences, 31, no. 3, 2015, p. 177.

57.DOĐRUER, Y., TELLY, N., TELLY, A.E., KAHRAMAN, H.A., GUNER, A., Eurasian J ournal of Veterinary Sciences, 31, no. 3, 2015, p. 177. 58.SOUCI, S.W., FACHMANN, W., KRAUT, H., Food composition and nutrition tables, CRC Press, London, 1994, p. 80.

59.GRAUR, M., MIHAI, B., BOTNARIU, G., POPESCU, R., LACATUSU, C., MIHALACHE, L., RACARU, V., CIOCAN, M., COLISNIC, A., POPA, A., LUPU, S., FILIP, L., Ghid pentru alimentatie sanatoasa, Ed. Performantica, lasi, 2006, p. 39.

60.LEAN, M., COMBERT, E., Barasi's Human Nutrition a health perspective, $3^{\text {rd }}$ edition, CRC Press, Taylor \& Francis Group, 2017, p. 35.

61.WHITNEY, E., ROLFES, S.R., Understanding nutrition, $12^{\text {th }}$ editions, Wadsworth Cengage Learning, 2011, p.187.

62.GUYOT, N., JAN, S., REHAULT-GODBERT, S., NYS, Y., GAUTIER, M., BARON, F., World's Poultry Science J ournal, 69, Supplement, 2013, p. 1.

63.STADELMAN, W.J ., Egg - structure and composition, Encyclopaedia of Food Science and Nutrition, 2003, p. 97.

64.KUKSIS, A., Biochim. Biophys. Acta, 1124, 1992, p. 205.

65.LANDS, W.E.M., Egg nutrition and biotechnology, CABI Publishing, Wallingford, Oxon., UK, 2000, p. 35.

66.LEAF, A., KANG, J.X., XIAO, Y.F., Egg nutrition and biotechnology, CABI Publishing, Wallingford, Oxon., UK, 2000, p. 25.

67.BADR, H.M., Food Chemistry, 97, 2006, p. 285.

68.HUOPALATHI, R., LOPEZ-FANDINO, R., ANTON, M., SCHADE, R., Bioactive Egg Compounds, Berlin, Heidelberg, Springer, 2007, p. 117. 69.BOSCHIN, G., D'AGOSTINA, A., ANNICCHIARICO, P., ARNOLDI, A., Food Chem., 108, 2008, p. 600.

$\overline{\text { Manuscript received: } 23.09 .2018}$ 